\title{
JUDICIAL REVIEW OF LEGISLATION BY ADMINISTRATIVE BODIES AND NATIONAL COUNCIL OF JUSTICE: LIMITS AND POSSIBILITIES IN DIALOGUE WITH CONSTITUTIONAL JURISDICTION
}

\section{CONTROLE DE CONSTITUCIONALIDADE DE LEI E CONSELHO \\ NACIONAL DE JUSTIÇA: LIMITES E POSSIBILIDADES EM DIÁLOGO COM A JURISDIÇÃO CONSTITUCIONAL}

PAULO GONET BRANCO

Professor of Law at Brasiliense Institute of Public Law (IDP). PhD in Law at the University of Brasilia (UNB) and Master in International Human Rights at the University of Essex, UK. E-mail: pgbranco@gmail.com.

\section{ILTON NORBERTO ROBL FILHO}

Professor of Law at IDP and at Federal University of Paraná (UFPR). Post-Doctorate in Constitutional Law at Pontifical Catholic University of Rio Grande do Sul (PUCRS) and PhD in Human Rights and Democracy at UFPR. E-mail: norbertorobl@gmail.com.

\begin{abstract}
Objectives: The constitutional powers of the National Council of Justice challenge a constitutionally appropriate interpretation of its functions and constitutional consequences. This article analyzes the incidental control of constitutionality of administrative acts by such Council, based on article 37 of the Constitution of 1988, with the possibility to decline application of the law interpreted as unconstitutional.

Methodology: The methodology used in this study is phenomenological-hermeneutic with literature review and analysis of the jurisprudence of the National Council of Justice and the Federal Supreme Court.

Results: The thesis sustained in this paper states that the control of constitutionality of laws by administrative bodies loses relevance with the adoption of a robust system of judicial review in incidental and abstract forms, as currently observed in Brazil. On
\end{abstract}


the other hand, exceptionally, due to the powers of article 103-B, I and II of $\S 4$ of the Federal Constitution, the National Council of Justice may carry out judicial review by administrative bodies, having as its control parameter especially article 37 of Federal Constitution, but with limitations and due deference to the precedents of the Federal Supreme Court to apply the constitutional principles of government and to resolve the conflict between constitutional norms.

Contributions: The study mentions the peculiarities of the National Council of Justice (instituted by Constitutional Amendment No. 45/2004) that are of special interest to analyze its institutional design and its place in rule of law, discussing the possibility of judicial review of administrative acts by the National Council of Justice with the nonapplication of laws not yet declared unconstitutional by the Courts.

KEYWORDS: National Council of Justice; judicial review by administrative bodies; jurisdiction; Federal Supreme Court.

\section{RESUMO}

Objetivos: As competências constitucionais do Conselho Nacional de Justiça desafiam uma interpretação constitucionalmente adequada das funções e das suas consequências constitucionais. Este artigo analisa o controle incidental de constitucionalidade dos atos administrativos do mencionado Conselho, a partir do art. 37 da Constituição de 1988, com a possibilidade de afastamento da lei interpretada como inconstitucional.

Metodologia: A metodologia utilizada neste estudo é fenomenológico-hermenêutica com revisão da literatura e análise da jurisprudência do Conselho Nacional de Justiça e do Supremo Tribunal Federal.

Resultados: A tese sustentada neste trabalho afirma que o controle de constitucionalidade de leis por órgãos administrativos perde relevância com a adoção de robusto sistema de controle judicial de constitucionalidade nas modalidades incidental e abstrata, conforme se observa atualmente no Brasil. De outro lado, excepcionalmente em razão das competências dos incisos I e II do § 4‥ do art. 103B, da Constituição de 1988, o Conselho Nacional de Justiça pode realizar controle administrativo de constitucionalidade, tendo como parâmetro de controle especialmente o art. 37 da Constituição de 1988, mas tendo limite e devendo deferência à jurisprudência do Supremo Tribunal Federal para concretizar os princípios constitucionais da administração pública e para solucionar a colisão entre normas constitucionais.

Contribuições: $O$ estudo traz as peculiaridades do Conselho Nacional de Justiça (instituído pela Emenda Constitucional no. 45/2004), que são de especial interesse para analisar-se sua estrutura institucional e seu lugar no regramento do Direito ao 
discutir a possibilidade de revisão judicial de atos administrativos pel Conselho Nacional de Justiça co a não aplicação de leis ainda não declaradas inconstitucionais pelos tribunais.

PALAVRAS-CHAVE: Conselho Nacional de Justiça; controle de constitucionalidade administrativo; jurisdição; Supremo Tribunal Federal.

\section{INTRODUCTION}

Since the discussions over the creation of a Justice Council to expand the mechanisms of control and accountability in the Judiciary branch, there has been controversy over the powers that this body should exercise due to the possibility of affronting the institutional independence and the decision-making independence of members of the judiciary.

The Federal Supreme Court (STF) in Abstract Judicial Review (Direct Action of Unconstitutionality - ADI) №. 3367 deemed the creation of the National Council of Justice (CNJ) constitutional by Constitutional Amendment (EC) ㄲo. 45/2004, stating that this constitutional body is exclusively administrative in nature and has no jurisdiction over the STF. This article deals with the powers of the CNJ provided in items I and II of article 103-B, paragraph 4, CF/88, which consist of the power to regulate and control the acts of magistrates and judicial bodies subject to the supervisory power of the Council.

The peculiarities of the body make it of special interest to analyze its institutional design and its place in rule of law, discussing the possibility of judicial review of administrative acts by the CNJ, with the non-application of laws not yet declared unconstitutional by the Courts.

Thus, section 2 of this article deals with the Rule of Law in the 1988 Federal Constitution, the Brazilian justice system and the institutional design of the National Council of Justice. Subsequently, section 3 reflects on the first opinions of the Federal Supreme Court of the powers of the National Council of Justice, these precedents being the first layer of understanding of the Council's constitutionally appropriate 
sphere of action.

On the other hand, section 4 analyses the new understanding of the STF in relation to the constitutional role of the CNJ, stating in some Federal Supreme Court judgments that the Council may rule out the application of laws that have not yet been declared unconstitutional in court in certain cases. This current moment is referred to as the second layer of the STF's understanding of the powers of the Council. Section 5 presents the limits and possibilities for the CNJ to carry out incidental control of constitutionality administratively (judicial review by administrative bodies). Finally, the conclusions are stated in section 6.

\section{STRENGTHENING THE RULE OF LAW AND INSTITUTIONAL DESIGN OF THE NATIONAL COUNCIL OF JUSTICE}

The institutional design of the 1988 Constitution strengthened the justice system in a unique way in our history. Some reasons can be listed for this phenomenon.

In the first place, in contemporary constitutional democracies, the Courts are guardians of the Constitution ${ }^{1}$, having as their constitutional mandate the protection of fundamental rights, the control of state and political power and the maintenance of the rules of the democracy. It should not be forgotten that the 1988 Federal Constitution (CF/88) is an important in the transition to a democratic regime ${ }^{2}$. It seeks to overcome hyper-presidentialism with a more adequate and balanced horizontal distribution of state powers amongst the executive, legislative and judicial branches of government, in addition to securing important roles to constitutionally autonomous institutions such as the Public Prosecution Service (Ministério Público) and the Public Defender's Office (Defensoria Pública) $)^{3}$. It was also observed the greater constitutional scope of the

\footnotetext{
${ }^{1}$ On this issue, see cf. KELSEN, 1995; FIOROVANTI, 2001; COSTA, 2006, p. 95-198; ROBL FILHO; SCHELEDER, 2016, p. 9-41. Para uma visão crítica, cf. JONES, p. 773-806, Spring 2019.

2 See O'DONNELL, 1998, p. 27-54; ROBL FILHO, 2012, p. 66-95.

${ }^{3}$ On hyperpresidentialism, see MACEDO, 2014, p. 496-518.
} 
Brazilian justice system, which is in tune with the worldwide trend movement on the expansion of the recognition of fundamental and human rights with the consequent possibility of immediate invocation of these rights in courts, extending the adjudication of numerous social phenomena ${ }^{4}$.

In this context, the Original Constituent Power and the Derived Constituent Power establish the administrative, financial and budgetary autonomy of the Judiciary, essential for the exercise of their constitutional attributions ${ }^{5}$. Administrative autonomy consists of the power to choose members and auxiliary services, in particular by means of a public exam, as well as the organization of jurisdiction. On the other hand, budgetary autonomy is expressed in the participation in the preparation of the Budgetary Annual Guideline (LDO) and in the preparation of a budgetary proposal, observing the LDO. The proposal must necessarily be compiled by the Executive Branch and sent to the Legislative Branch for it to carry out its deliberations. In turn, financial autonomy concerns especially the use and management of the resources that are allocated to the Judiciary 6 .

The members of the Judiciary (Judges and Justices) are invested in a lifetime position, only losing the position by judicial decision. They are also invested with immovability, which prohibits the change of the previously assigned jurisdictions, with the exception of the possible application of sanctions for disciplinary offences and situations that a judge is need in other place. Lastly, they are invested with irreducibility of salary, which prohibits the reduction of the nominal value of salaries. These guarantees are essential for the maintenance of the functional independence of the members of the judiciary; that is, they are intended to ensure that judges are able to exercise their constitutional and legal functions in a manner that is free from unnecessary interference, with a view to ensuring that the decisions are taken exclusively in the light of the reasonable interpretation of the law.

However, it is not uncommon accountability lapses in the Judiciary, which led to the enactment of Constitutional Amendment no. 45 of 2004, under the terms of article

\footnotetext{
${ }^{4}$ See FEREJOHN, 2002, p. 41-69.

${ }^{5}$ See CLĖVE, 2011, p. 659-675.

${ }^{6}$ See ROBL FILHO, 2013, p. 130-179.
} 
$103-\mathrm{B}, \mathrm{CF} / 88^{7}$. The duty of authorities and bodies to provide information and to provide justifications for their actions and omissions, which, if unsatisfactory, imply financial, administrative or criminal ${ }^{8}$ penalties, is inherent to democratic accountability.

The constitutional powers of $\mathrm{CNJ}$ is exercised mainly as an administrative and financial control of the Judiciary and as an inspection of the fulfillment of the law duties of its members (art. 103-B, $\S 4$, caput, $\mathrm{CF} / 88$ ). The constitutional norm gives the CNJ the power to ensure the autonomy of the Judiciary and compliance with the Statute of Judicature (Estatuto da Magistratura), exercising it regulatory power and suggest measures in its field of action.

The Constitution charges the Council to ensure compliance with the constitutional principles of Public Administration (legality, impersonality, efficiency, morality and publicity). The literal expression of the constitutional text states that the $\mathrm{CNJ}$ is responsible for nullifying and reviewing administrative acts that violate legality practiced by members of the judiciary and judicial bodies, and for determining measures for the precise compliance with the law (articles 103-B, paragraph 4, II, $\mathrm{CF} / 88$ ). The competence enshrined in clauses I and II of Paragraph 4 of Article 103$\mathrm{B}, \mathrm{CF} / 88$ are the specific object of study of this article.

$\mathrm{CNJ}$ composition is essential to understand its powers. The Presidency of the Council is attributed to the President of the Federal Supreme Court, also including a Justice of the Superior Court of Justice (STJ), a Justice of the Superior Court of Labor (TST), a Labor Appellate Justice and a Labor Judge, appointed by the TST, a State Justice and a State Judge, appointed by the STF, a Federal Appellate Justice and a Federal Judge, appointed by the STJ, thus $60 \%$ of the members are Judges or Justices, according to art. 130-A, I to IX, CF/88.

The Council is also composed of two lawyers appointed by the Federal Council of the Brazilian Bar Association (OAB) and two citizens with outstanding legal knowledge, one appointed by the Chamber of Deputies and the other by the Federal Senate, pursuant to Articles $103-\mathrm{B}, \mathrm{V}$ and $\mathrm{VI}, \mathrm{CF} / 88$. Finally, the $\mathrm{CNJ}$ is composed of

7 See TOMIO, 2013.

${ }^{8}$ On the analytical concept of accountability, cf. SCHEDLER, 1999, p. 13-28. 
a member of the Public Prosecution Service of the Union (Ministério Público da União) and a member of the State Public Prosecution Service (Ministério Público Estadual) appointed by the Attorney General of the Republic.

This composition led Gilberto Bercovici to point out that the $\mathrm{CNJ}$ is not a body of external control of the judiciary, but of internal control (accountability) ${ }^{9}$. This same conclusion was reached on the direct action of unconstitutionality that was filed against the very creation of the council (STF, 2005).

It should be noted that relevant constitutional bodies such as the Federal Supreme Court, the Superior Court of Justice, the Attorney General's Office, the Federal Council of the Brazilian Bar Association, the Chamber of Deputies and the Federal Senate make the nominations for the composition of the CNJ, which must be approved by an absolute majority of the Federal Senate in order for appointments to take place subsequently by action of the President of the Republic. Thus, the nomination process involves important institutions and especially important legal actors, allowing complex and constitutionally appropriate a priori legal analyses, a particularity that also influences the question of the possibility of a certain judicial review by the administrative body, as will be addressed at the end of this article.

The Presidency of the CNJ is attributed to the President of the Federal Supreme Court, head of the National Judiciary. The Attorney General of the Republic or his representative has the right to speak (voice) in the Council. These relevant actors of concentrated and abstract judicial review participate, therefore, in the CNJ, which points positively to the technical capacity of the body to carry out judicial review.

\section{FIRST LAYER: THE CNJ'S POWERS AND ITS SCRUTINY BY THE STF}

J.H. Weiler proposes an analysis of the law as geological layers (WEILER, 2004, p.548-549), and this conception can be adopted in Constitutional Law (CANOTILHO, 2008, p.325-334). The case law of the Federal Supreme Court on the

${ }^{9}$ On this theme, BERCOVICI, 2005, p. 185-191. 
National Council of Justice can be examined in this way. There are STF decisions that establish the structure and the main concepts of the CNJ's powers, making up the first geological layer. Subsequently in the second geological layer, in view of new developments in reality, the jurisprudence on the powers of the body is refined, producing a resized geological design.

In a first of these layers (moments), the STF took care to establish the basic understanding on the competencies of the $\mathrm{CNJ}$ and especially on clauses I and II of

$\S 4$ of art. 103-B, CF/88. In this context, the STF's essential judgment on the powers of the CNJ in Direct Action of Unconstitutionality (ADI) n‥ 3367, which ensured the constitutional legitimacy of the creation of the Council.

In the opinion, the Federal Supreme Court understood that: a) there is no violation of the irrevocable clause of the separation of powers in the creation of the $\mathrm{CNJ}$, since it is a matter of internal administrative, financial and disciplinary control of the judiciary and not external control; b) the CNJ does not violate the essential (political) core of the separation of powers, because this Council has only an administrative functions, maintaining the impartial jurisdictional function and independent of magistrates and courts; c) the Council is located under the STF in hierarchy, not exercising control over the top body of the national judiciary in Brazil;

d) The Judiciary Power is national, having a unitary character, therefore the Federal Justice and the State Justice are organs that compose the Brazilian national judiciary, not existing a Judiciary Power of the federal entity Union and Judiciary Powers of each one of the member states; e) since the Judiciary Power is national, it is not possible constitutionally to establish State Justice Councils; and f) citizens with notorious legal and moral knowledge indicated by the Chamber of Deputies and the Federal Senate and lawyers in the exercise of the function of Councilors can only work supplementary in one teaching position, since they act as Justices.

The STF recognized the need to improve the self-government of the Judiciary and expand the internal control mechanisms over judges, which until then had been substantially centered on the co-regulatory bodies of the courts (STF, 2005, p.229232).

The decision in ADI №. 3367 was based on the literal understanding of 
subparagraph ' $r$ ' of item I of art. 102, I, 'r', CF/88 resulting from the Amendment to the Constitution no. 45/2004, when it affirmed the powers of the STF to analyze actions against acts of the $\mathrm{CNJ}$, instituted by the constitutional reform as a body of the National Judiciary, necessarily submitted to the scrutiny of the Court located at the top of the judicial structure (STF, 2005, p.255-256).

It was pointed out that it was not intended that the exercise of constitutional powers of the $\mathrm{CNJ}$ could undermine the independence of magistrates in the provision of jurisdiction. The independence of the judiciary remained untouched (STF, 2005, p.280-282).

Diverging from the formed majority, it is of interest to register the vote of Justice Marco Aurélio due to the unconstitutionality of the provisions of EC no. 45 relating to the CNJ. One of the foundations he presented is expressed in the warning that "we cannot be naive enough to believe that the activity to be developed by the National Council of Justice will not have repercussions on the judicial office, exercised by human beings", to which he added his conviction of not being able "to imagine a body of the Judiciary that does not exercise the judicial office itself" (STF, 2005, p.310-317). This warning from Justice Marco Aurélio hovers today, impacting, on some decisions and acts of the $\mathrm{CNJ}$ that influence the exercise of jurisdiction.

Still, and notwithstanding the persuasive power of the arguments centered on the national character of the Judiciary, presented by the Rapporteur of ADI no. 3361, one cannot easily deny the existence of a certain judicial federalism resulting from the recognition of the autonomy of the state judiciaries, bearing in mind that "the establishment of a composite State, autonomous or federal, (...) will have consequences on the configuration of the legislative and executive powers, as well as (...) on the judiciary operating in these systems"10.

Another relevant judgment of the Federal Supreme Court on the powers and constitutional status of the CNJ was Declaratory Action of Constitutionality Temporary Injunction (ADC) no. 12, regarding the constitutionality of the Resolution

\footnotetext{
${ }^{10}$ RUIZ, 1994, p. 15. In the: "El establecimiento de un Estado "Compuesto", autonómico o federal, (...) tendrá consecuencias no sólo en la consiguiente configuración de los poderes legislativo y ejecutivo sino también (...) en el poder judicial operante en dichos sistemas"..
} 
CNJ n․ 07/2005 that prohibits nepotism in the Judiciary branch. In addition, this trial is part of the first layer of the decisions of the STF defining the normative feature of the CNJ.

The reasons and grounds for the judgment in the ADC were reaffirmed in the final judgment on the merits, distinguishing the following arguments: a) as can be comprehended from the Constitution, the CNJ's regulatory power involves the possibility of innovating the legal system, expressing primary normative will; b) the powers can be described from one unexpressed core and four expressed cores, the latter being composed 1. for ensuring the observance of the constitutional principles of government, 2. assessing the legality of the acts practiced by the Judiciary, 3. nullifying illegal acts and setting deadlines for the necessary measures for the faithful compliance with the law and 4. analyzing the efficiency, effectiveness and economy of the management of the Judiciary, c) the unexpressed nucleus of competence encompasses the possibility of creating primary normative acts on issues included in the expressed nucleus, d) the CNJ can directly apply the Federal Constitution within the scope of its constitutional powers and e) the judiciary in Brazil, despite the existence of state courts and magistrates, is national in character; thus both the federal and the state courts make up the national judiciary (STF, 2006a).

In his opinion, Ministro Menezes Direito declared the complex constitutional role of the National Council of Justice, which, despite being an administrative and nonjudicial body, uses traditionally jurisdictional expedients, such as the granting of precautionary measures in its administrative proceedings and procedures. It also registered the constitutional competence of the $\mathrm{CNJ}$ to put into effect the constitutional principles set forth in art. 37, caput, CF/88 (STF, 2006a). This power of the CNJ will be useful for the analysis of the possibility of the incidental judicial review in the trial of cases by the Council ${ }^{11}$.

After the judgment of ADI n․ 3367 and ADC n‥12, two other essential issues for the configuration of the CNJ were the object of the attention of the STF: a) the delimitation of the power of the Federal Supreme Court to analyze the acts of the CNJ

${ }^{11}$ On this complex regulatory power of the $\mathrm{CNJ}$ and the need to respect fundamental rights, see ROBL FILHO, 2017, p. 40 - 67. 
(art. 102, I, 'r', CF/88) and b) the construction of the role of the CNJ in judicial review of administrative and normative acts, the latter being viewed as the second layer of the current structure of the CNJ. The Federal Constitution establishes, in article 102, I, that it is originally the responsibility of the Federal Supreme Court, preciously, to safeguard the Constitution, and is responsible for processing and judging, originally, "r) litigation against the National Council of Justice and against the National Council of the Public Prosecution Service". This wording allows us to say that the Federal Supreme Court has jurisdiction to review any and all acts of the CNJ that may be the subject of litigation that fall within the original jurisdiction of the Supreme Court.

Apart from these instruments, the STF ruled that it is not possible to file popular action (ação popular) against acts of the National Council of Justice. The exception to this rule is subparagraph ' $n$ ' of Section I of Article 102, CF/88, which establishes the jurisdiction of the Federal Supreme Court over "actions in which all members of the judiciary are directly or indirectly interested, and those in which more than half of the members of the court of origin are prevented or directly or indirectly interested" and in the case of a dispute between the Union and a Member State (STF, 2006c).

On the other hand, precedents of the Federal Supreme Court has clarified that, when the National Council of Justice maintains acts and decisions of other bodies and judges in a lawsuit, therefore, that does not impose an active behavior for the bodies it inspects, it does not open competence for the Supreme Court to review the deliberation of the CNJ. Thus, if the Council considers valid a provision issued by the Court of Justice or a judgment rendered in a disciplinary proceeding by a competent body of the Federal Regional Court, the act of the CNJ will not have altered what already exists, not attracting the jurisdiction of the STF ${ }^{12}$. The applicable lawsuit is restricted to those filed against the positive act of the $\mathrm{CNJ}$.

Furthermore, the Federal Supreme Court understands that only the Constitutional Actions (Writ of Mandamus, Habeas Data, Habeas Corpus and Writ of Injunction) against acts of the CNJ are of its jurisdiction, and the ordinary actions are of the jurisdiction of the Federal Judges. There are two main arguments that support

${ }^{12}$ See STF, 2011b. 
this position: a) the fact that the list of powers of the Federal Supreme Court is exhaustive and strict and b) the fact that, in civil lawsuits, it is the Federal Government, and not the CNJ, that is the respondent ${ }^{13}$. Thus, it would not be applicable Original Civil Actions against acts of the CNJ, because the legitimacy of the Federal Government imposes the judgment by the federal district judge ${ }^{14}$.

This understanding induces practical and systematic problems. The composition of the National Council of Justice includes the President of the Federal Supreme Court, a Justice of the Superior Court of Justice, a Justice of the Superior Labor Court and a Justice of the Federal Regional Court. In this way, the situation arises, which gives rise to some perplexity and risk to the functionality of the system, of a federal district judge finding himself in the position of reviewing a legal opinion of body of 15 (fifteen) Counselors, among them the President of the Federal Supreme Court and other members of Superior Courts and of appellate courts.

Even greater perplexity regarding the functionality of the judicial system, especially with regard to the independence of the judiciary, led to Recommendation $\mathrm{n}^{\circ}$. 38 of the National Inspector General's Office of Justice of 2019. The act orders the Courts "to comply with the normative acts and decisions rendered by the National Inspector General's Office of Justice, even if there is a contradictory judicial order, except if it comes from the Federal Supreme Court" (CNJ, 2019). The Recommendation leads to judges and appellate justices ceasing to fully exercise the jurisdiction in which they are constitutionally vested. Otherwise and in MS (Writ of Mandamus) $\mathrm{n}^{\circ} .36549 \mathrm{MC}^{15}$, the conclusion was the unconstitutionality of the agency's interference with the judge's independence.

\footnotetext{
${ }^{13}$ See STF, 2013.

${ }^{14}$ On the issue of the exercise of constitutional jurisdiction and its impact on the provision of the jurisdiction and especially on this understanding of the STF, see MARRAFON; ROBL FILHO, 2014, p.1441-1442.

${ }^{15}$ Rel. Min. Marco Aurélio, DJe 1-7-2019.
} 


\section{SECOND LAYER: THE CNJ'S JUDICIAL REVIEW AND THE STF'S DECISIONS ON THIS MATTER}

A more complex issue relates to the possibility of the National Council of Justice judging the constitutionality of normative acts, ruling out the application of laws not yet considered unconstitutional in court, which have been invoked as grounds for lawsuits of agents submitted to the supervision of the Council. An overview of STF precedents in this regard may entangle the observer in uncertainty. The issue has to do with the possibility of non-judicial and administrative bodies refusing to apply laws they consider unconstitutional.

When 1988 Constitution came into force, the STF proclaimed that "the Executive and Legislative Branches may declare their administrative acts null (...) on the grounds of illegality or unconstitutionality, and not laws or acts with the force of law," since "it is the private responsibility of the Judiciary to declare them unconstitutional" (STF, 1990). Therefore, only in the exercise of a jurisdictional power would the system of separation of powers allow the declaration of unconstitutionality of the law.

At the same time, several monocratic decisions by STF members between 2006 and 2010 gave rise to the thesis that not even the Federal Court of Accounts (TCU) could rule out the law as unconstitutional, and that the Súmula (Ancient Precedent) 347 that admitted it had been overruled. The premise of the reasoning was that, by nature, the declaration of unconstitutionality is a jurisdictional act and that only the exception to the TCU was admitted, because there were not, under the Constitution of 1946, in force at the time of the precedent, expeditious means to provoke the judiciary to proclaim the law is unconstitutional, in time to perform the analysis of the act submitted to the Court of Accounts (Tribunal de Contas). With the current expansion of abstract judicial in Brazil, the problem no longer required an exceptional solution. Justice Gilmar Mendes took the pioneering decision along these lines when he granted, monocratically, a writ of mandamus (STF, 2006b). In addition to that decision, there 
were several other decisions on similar grounds, all of which were monocratic. ${ }^{16}$

However, in 2011, the STF Plenary denied a writ of mandamus in which it attacked the CNJ's decision affirming the unconstitutionality of the state law (STF, 2011a). Law no. 8.943/2008 of the State of Mato Grosso attributed a percentage of court costs and notary fees to private entities. In the CNJ, the law had not been applied, even though it had not yet been the object of criticism in jurisdictional courts. The Council's decision was expressly based on STF rulings that were averse to the distribution of court costs to private entities (CNJ, 2009).

In the case, the Supreme Court refused the power of the CNJ to declare the unconstitutionality of the law, but maintained the Council's deliberation on its merits, declaring, the Court itself, incidentally, the unconstitutionality of the normative law of the Member State.

A second layer of STF jurisprudence on the competence of the CNJ and especially on clauses I and II of $\S 4$ of article $103-B, C F / 88$ is beginning to be formed, changing and deepening the reflection over legal perspectives and conceptions.

In 2016, the STF directly admitted the competence of the CNJ to rule out the application of a law that it considers unconstitutional, when this is indispensable for the evaluation of acts submitted to the inspection of the Council. The case in question concerned the dismissal of 100 (one hundred) commissioned (temporary) positions in the Court of Justice of Paraíba, which were provided for by State Law n‥ 8.223/2007.

The National Council of Justice understood that the state law violated the constitutional hypotheses of creation of positions in commission (temporary), under the terms of art. 37, II and V, CF/88 (CNJ, 2009). Thus, the administrative acts of appointment and inauguration practiced by the State Court of Justice were unconstitutional, and appointments by the Council were declared null. The

\footnotetext{
${ }^{16}$ See specific study of SINDIRECEITA, by CAVALCANTI, Alessandra Damian et al, mimeo, points out these other decisions, issued in Mandados de Segurança 25.986-MC/DF, Relator: Min. Celso de Mello, DJ 30/06/2006; 26.410-MC/DF, Relator: Min. Ricardo Lewandowski, DJ 02/03/2007; 27.837-MC/DF, Relator: Min. Gilmar Mendes, DJe 05/02/2009; 27.232-MC/DF, 27.337-MC/DF, 27.344-MC/DF e 28.252-MC/DF, Relator: Min. Eros Grau, DJe 20/05/2008, 28/05/2008, 02/06/2008 e 29/09/2009; 27.743-MC/DF, Relatora: Mina. Cármen Lúcia, DJe 15/12/2008; 26.783-MC/DF e 26.808-MC/DF, Relatora: Mina. Ellen Gracie, DJ 01/08/2007 e 02/08/2007; e na Ação Cautelar 1.193-MC-QO/RJ, Relator: Min. Gilmar Mendes, 2ª Turma, DJ 30/06/2006.
} 
unlawfulness (antijuridicidade) of State Law no. 8.223/2007 - a term used by the CNJ, not being used the word unconstitutionality - was taken as evidenced by the jurisprudence of the STF around other similar laws, mentioning the one that was violated in ADI no. 3.233 on 05/10/2017. The CNJ concluded that, in this case, "other is the law, other is the nomenclature of posts, other is their legal definition. However, the open exile of the constitutional requirements to regulate the provision of public offices (...) unfortunately persists" (CNJ, 2009).

It is interesting to note that initially the STF granted a precautionary measure to suspend the effects of the decision of the CNJ Plenary, which declared null the appointments of commissioned positions based on State Law №. 8.223/2007, understanding that the powers provided for in article 103-B, paragraph 4, II, CF/88 did not allow the declaration of unconstitutionality of such law (STF, 2009). In sum, the injunction held that the CNJ was not competent to declare the law unconstitutional, following the position established by the STF in the first layer of the constitutional jurisdiction on the matter.

This opinion was reviewed in the substantive judgment of Petition 4656, when the STF Full Bench affirmed that it was possible for the Council to rule out the imposition of an unconstitutional law that has effects on acts performed or to be performed by agencies of the Judiciary, since article 103-B, paragraph 4, II, of the Constitution is responsible for ensuring compliance with article 37 of the same Constitution.

The opinion of the rapporteur, Justice Carmen Lúcia, can be summarized as follows (STF, 2016, fls.244-254): a) the President of the Republic and the autonomous administrative bodies, which must control the validity of administrative acts, must make an analysis of the constitutionality of laws that support administrative acts, b) this form of constitutionality control (judicial review by administrative bodies and agencies) is an implicit competence attributed to the $\mathrm{CNJ}, \mathrm{c}$ ) this is a legal understanding that corroborates the ideal of the open society of interpreters of the Constitution, d) the denial of the application of the law due to unconstitutionality depends on the vote of an absolute majority of its members, applying here also the constitutional clause of the plenary reserve established in article. 97, CF/88, e) after the conclusion of a concrete 
judgment that considered the law unconstitutional, the CNJ may use regulatory power "to impose on the bodies constitutionally submitted to its inspection activities the invalidity of an administrative act due to the inapplicability of the legal text (STF, 2016, fl. 249) " and f) this incidental judicial review in the administrative decision does not lead to the annulment or revocation of the law, which remains in force, until the STF declares it null.

In the trial, Justice Ricardo Lewandowski pointed out that the CNJ, there, "simply [invoked] precedents of the Federal Supreme Court itself, to determine the dismissal of those servants who were hired in disagreement with what the Constitution establishes in art. 37" (STF, 2016, fl. 279). The vote of Justice Luiz Fux emphasizes that the recognition of the competence of the CNJ to refuse to apply a law that he considers unconstitutional was being admitted, because the STF had already declared contrary to the Constitution law of practically the same content. He then refers to the point of view sustained at another time by Justice Gilmar Mendes that certain agencies, even not being charged with providing jurisdiction, could apply the position of the STF's case law to affirm the unconstitutionality of the law (STF, 2016, fl. 292).

Justice Luiz Fux then pointed out that the case heard by the CNJ involved a law substantially the same as another that the STF had already declared unconstitutional in a judicial review. He stated:

Thus, after the judgment of this Court - ADI 3.233 -, the purpose of the legislative changes is to maintain, under a new guise, the same content of the original rule, with the simple alteration of the respective name, remaining equal - and unconstitutional - the nature and attributions of the position (STF, 2016, fl. 302).

He went on to emphasize that the disregard of the law obeyed the intelligence already formed by the STF on the precise issue under discussion:

It is precisely for this reason that the CNJ Plenary considered it necessary to open, on its own initiative, an Administrative Control Procedure to investigate the possible repetition of the practice of irregular appointments of servants by the Court of Justice of the State of Paraíba, after which, identifying in the contested law the same defect that had tarnished the rules declared unconstitutional in Direct Action for Unconstitutionality 3.233, ordered the 
dismissal of commissioners (...). Such arguments can only confirm the reiterated and peaceful position of the Federal Supreme Court on the matter, so as to support the possibility of the National Council of Justice ruling out the application of the rule, as a sufficient argumentative burden, materialized in a previous analysis of this Court about the unconstitutionality of the matter conveyed to the CNJ (STF, 2016, fl.302).

Speaking specifically on the competence of the CNJ to refuse to apply the law on the grounds of unconstitutionality, the Justice emphasized the fact that the CNJ was dealing with the problem due to the performance of a task assigned to it by the constituent and the fact that the unconstitutionality was clear, since it reflected a situation already examined and judged by the STF (2016, fls.302-303):

\begin{abstract}
Finally, I refute the alleged incompetence of the CNJ, as an administrative body, to render the contested decision. In fact, the verification of administrative acts, including the appointment to commission positions in flagrant disrespect of the constitutional rule of public competition and the jurisprudence of the Federal Supreme Court, is in line with the provision of constitutional jurisdiction, which prescribes the jurisdiction of the National Council of Justice for the control of the administrative and financial performance of the Judiciary (CRFB/88, art. 1). 103-B, § 4), ensuring the observance of art. 37 and assessing, ex officio or through provocation, the legality of administrative acts performed by members or bodies of the Judiciary (CRFB/88, art. 103-B, § 4, item II). (...) However, in order not to vulgarize and broaden the jurisdiction of the National Council of Justice in an unlimited manner, it states, as a theoretical premise, that the removal of laws or normative acts should only occur in cases of complete and uncontested outrage to the Constitution - certainly enhanced by precedents of this Federal Supreme Court on the matter -, so that in situations of reasonable doubt about the content of the adverse rule, the option made by the legislator, invested which is in its prerogatives by popular baptism (...) should be respected.
\end{abstract}

The possibility judicial review by the CNJ was admitted, but in a peculiar situation.

Therefore, in a judgment of the National Council of Justice on February 20, 2018, Justice Cármen Lúcia stressed that the Council "was created as an administrative body. It is not a judicial body, does not exercise jurisdiction and does not declare any rule unconstitutional. Anything more than that is exorbitant of the Council's constitutional powers. It's that simple" (CNJ, 2018b). This was stated in Process $n^{\circ}$. 0001809-93.2016.2.00.0000, which involved the application of Bahia 
State Law no. 13.555/2016, establishing the Special Compensation Fund (FECOM) for notarial and registration activities.

In addition to providing compensation for free acts performed by civil registrars of natural persons and the granting of daily allowance for services that do not collect enough for their costs, this state law provided for the payment of salaries of public employees who still perform the notarial and registration activities that should be assigned to private individuals, although the fees in these "state-owned" services are assigned to the State, pursuant to State Law no. 13.555/2016.

The Rapporteur of Administrative Process, Minister Cármen Lúcia, based the impossibility for the CNJ to perform concrete and incidental constitutionality control (judicial review), in a monocratic decision of Justice Celso de Mello of June 18, 2018, in the Federal Supreme Court, which had dismissed the judgment of the CNJ (STF, 2018 $)^{17}$. In turn, the majority of Counselors Justices of the Council viewed the possibility of controlling the unconstitutionality of the allocation of funds from the FECOM in the Request for Providence no. 0001809-93.2016.2.00.0000, which is constituted by the collection of amounts from private users of notarial and registration activities for payment of the remuneration of public servants who temporarily perform notarial and registration services, as observed in the votes of Councilors Valdetário Andrade Monteiro, André Luiz Guimarães Godinho and Arnaldo Hossepian.

In any case, it can be said that the jurisprudential scenario is still not particularly clear when it comes to portraying the exact limits of the $\mathrm{CNJ}$ 's powers ${ }^{18}$.

17 Originated against the decision of the CNJ, 2013.

18 Recently, the Attorney General of the Republic expressed her opinion (PGR, N.o 59/2019 AJA/SGJ/PGR, sistema único $n .-$ PGR-MANIFESTAÇÃO-44629/2019) at STF, 2018, on the unconstitutionality of the decision of the CNJ in the Pedido de Providências $\mathrm{n}^{\circ}$. 000523038.2009.2.00.0000, Relator: José Adonis Callou de Araújo Sá, Julgamento: 01/06/2010, which imposed on the Court of Justice of the State of Bahia to cease applying Resolution $n^{\circ}$. 1/1992 for violation of constitutional provisions. This determination by the $\mathrm{CNJ}$ is also suspended due to another injunction granted by Justice Celso de Mello. 


\section{LIMITS AND POSSIBILITIES OF JUDICIAL REVIEW BY THE NATIONAL COUNCIL OF JUSTICE WITHIN THE FRAMEWORK OF THE RULE OF LAW. A MATTER OF COMPETENCE (POWER)}

The issue of the possibility of administrative bodies carrying out judicial review is not definitively settled, and there is no sure consensus over this matter not even of comparative law.

In Brazil, Gilmar Mendes (1997, p.18-19) and Lucas Catib de Laurentiis (2012, p.141-142) suggest that the possibility of non-application of the law understood as unconstitutional by the Public Administration was defended with persuasive arguments before the advent of abstract judicial review, instituted by Constitutional Amendment no. 16/1965. The reason was based on the difficulty of the administration to obtain judicially the declaration of nullity of the law due to formal or material defects of constitutionality. Only the Office of the Attorney General of the Republic was in charge of judicial review lawsuits. The holder of the office remained in charge as long as he enjoyed the confidence of the authority who appointed him, the President of the Republic.

With the 1988 Constitution, there are many plaintiffs in the Direct Action of Unconstitutionality, encompassing authorities that previously did not have access by themselves to this instance.

The phenomenon expanded with the creation of abstract state judicial review, for the judicial review of municipal and state laws in light of the State Constitution. The Allegation of Disobedience of Fundamental Precept (ADPF) has opened even more space for the jurisdictional unleashing of constitutional controversies. This new system of judicial review with the possibility of granting precautionary measures decreased the need for administrative authorities having to make their own judgments on the validity of the law - a task, not infrequently, of complex multidisciplinary overlaps that require unique legal expertise. ${ }^{19}$

\footnotetext{
${ }^{19}$ On this theme: MARRAFON, 2010. In STF, Justice Gilmar Mendes' decision in MS 25,888, when granting the request for an injunction to suspend the effects of the decision rendered by the Federal Court of Accounts: "It is necessary to take into account that the constitutional text of 1988 introduced a
} 
It is also important to remember that administrative bodies are often focused on their immediate problems and interests and are not able to do complex constitutional interpretation.

The Executive Power and administrative bodies often find themselves entangled in party political agendas, being constrained by strategies aimed at seeking immediate popular support, which are not always in line with the counter-majority implications involved in an adequate appreciation of the constitutionality of laws.

In the current context of diversification of mechanisms of access to jurisdictional judicial review, finally, the reasons for granting the administration the power to refuse the application of the law on grounds of unconstitutionality have been largely emptied. This does not mean that the administrative bodies are not subject to the Federal Constitution nor does it disregard the ideal of an open society of interpreters of the Constitution ${ }^{20}$, in which also non-judicial entities are called, in various ways, to implement the Constitution. The problem is solved, in reality, as a matter of competence (power).

This discussion, as can be seen, focuses on an investigation into the power of a body with an administrative mission to refuse to apply a law by arguments of unconstitutionality.

This literature is particularly scarce in Brazil, which, when it approaches the problem, devotes few pages of attention to it. André Salgado de Matos, on this matter, notes that the scenario is similar in Portugal, noting that "[...] a superficial heuristic analysis immediately reveals the scarce depth reached in general by the doctrinal treatment of the subject" (MATOS, 2004, p.153). It is reported that authors of renowned reputation, but who form a minority, affirm that it is up to the Administration to suspend its decision, while waiting for a position of the courts, or affirm the absolute incompetence to refuse application the law for reasons of constitutionality. The majority

radical change in our system of judicial review. (...) The broad legitimacy given to abstract judicial review, with the inevitable possibility of submitting any constitutional matter to the Federal Supreme Court, brought about a substantial change in the model of judicial review (...). It seems almost intuitive that, by significantly widening the circle of entities and bodies legitimized to provoke the Federal Supreme Court in the process of abstract control of rules, the constituent ended up restricting, in a radical way, the amplitude of the diffuse control of constitutionality".

${ }^{20}$ See HÄBERLE, 1997. 
would, however, be inclined to admit a limited and exceptional attribution to this. Nobody ventures to maintain that there is an unrestricted power of the administration in this area (MATOS, 2004, p.153-156).

In Spain, the author reveals surprise at the lack of interest in this theme (MATOS, 2004, p.128) While in the German scholarship is marked by more intense debates:

The admission of a competence of unrestricted non-application is a minority (...) The generality of the doctrine is divided between the acceptance of a competence of limited or exceptional non-application and its total rejection (MATOS, 2004, p.120-121).

It is interesting to note that the terms in which this controversy develops in foreign doctrine corresponds to the arguments that, without seeking support in national or comparative literature, are raised both in the $\mathrm{CNJ}$ and in the STF.

The reasons against which non-judicial bodies could refuse to apply laws that they consider unconstitutional are based on the idea that a Power would only be legitimized to interfere in the exercise of the legislative power to the extent that it received its own constitutional mandate for this - which would exclude the possibility of judicial review by administrative bodies, in application of the principle of separation of powers. It is common for the assertion to be made that administrative bodies are governed by the principle of legality, reinforced by the presumption of constitutionality of laws, which should only be removed by judges.

No less significant is the argument that arises from the presumption of constitutionality of laws, in the sense that overcoming the prima facie validity of laws requires robust conviction about the defect of unconstitutionality, to be achieved with consistent legal analysis, which requires specialized knowledge and practices, alien to the vast majority of administrative bodies.

Moreover, it is certain that reasons of legal security are added against the recognition of the competence of administrative entities to refuse a law because they see in it hostility to the Constitution. In terms of legal certainty, there is a danger that the judicial review by administrative bodies may consolidate individual situations that 
are difficult to reverse if the constitutional jurisdiction understands that the administrative assessment was wrong.

These are serious reasons why, at least as a general rule, the administrative review of the constitutionality of the laws is not accepted as correct.

On the other hand, it should also be noted that, in certain cases, the solution of suspending the administrative act affected by the law that the bureaucratic authority considers unconstitutional is not favored by basic principles of the constitutional order. The constitutional guarantee of speedy trials - which includes administrative proceedings - will be victimized by the provision. The idea of chaining the issue up the steps of the functional hierarchy to the authority that may eventually provoke judicial review faces the obstacle of the delay that this matters for the administrative action.

In addition, not all administrative authorities have legal standing to bring a direct action of unconstitutionality. It should also be remembered that the proposition of the action itself falls within the domain of the discretion of the legitimate ones (plaintiffs).

It should be considered that it sounds anachronistic to refuse, in the name of the principle of legality, the function of the Constitution as a parameter for the Administration. The Constitution is part of the "block of legality" to which the Administration must subordinate. The application of the law to the detriment of the Constitution also violates legality, as the model of separation of powers from the liberal State, coined to reduce the Administration to the exclusive role of the arm of pure and simple execution of the legislator's orders, has been superseded. Once the supremacy of the parliament is overcome, the moment is to observe the supremacy of the Constitution, and there is not enough reason to exclude the Administration from this paradigm.

The model of linking all powers to the Constitution, in turn, encourages a structure of mutual control of powers. If there is insecurity in the fact that the Administration may refuse to apply an unconstitutional law, there is also insecurity in the model of jurisdictional judicial review, especially when the diffuse model is admitted. Certainly, in the latter case, insecurity is of minor importance, but it cannot 
be ruled out. What seems to be decisive is to assess the degree of insecurity that society is willing to tolerate. In this regard, it should be noted that unconstitutionality presents different levels of difficulty in its perception and different risks arising from its affirmation by administrative bodies.

On the other hand, if it is true that there are differences in the application of legal techniques among the various agencies of the Administration, it is no less correct to bear in mind that some of them are necessarily composed of professionals who must show refinement in their dealings with the Law. If the systemic risks of the admission of judicial review by administrative bodies in these cases do not disappear, they become less intense.

Those ponderations are relevant to those who do not entirely deny the possibility of judicial review by administrative bodies, when it is indispensable to prevent or remedy significant damage. Hence the fact that where this administrative control is admitted, it is subjectively restricted and limited to hypotheses closer to the extraordinary.

\section{CONCLUSION: THE CNJ AND THE POSSIBILITIES OF JUDICIAL REVIEW BY ADMINISTRATIVE BODIES}

The Constitutional Amendment no. 45/2004 instituted the National Council of Justice, committing it to ensure the observance of art. $37, \mathrm{CF} / 88$. These principles of legality, impersonality, morality, publicity and efficiency incorporate notions of open denoting context, requiring concretization by the applicator / interpreter (in this case, the $\mathrm{CNJ}$ ), which, not infrequently, is called to resolve collisions between law and constitutional values. The Council was conceived with a singular composition ${ }^{21}$, but, although it is established that it is a body of the national Judiciary Power, but with no jurisdictional attributions.

Given these relevant features, it can be seen that, intuitively, the STF's case

${ }^{21}$ See item 2 above. 
law takes into account the factors mentioned above as relevant to resolve the issue of the admissibility of administrative judicial review.

From the examination of the precedents collected, it can be seen that the Supreme Court is averse to admitting that the CNJ exercises some kind of abstract judicial review. The agency's actions must be based on concrete situations, even though the STF has shown itself to be tolerant of issuing guidelines arising from the judgment rendered by the Council. ${ }^{22}$ It turns out that the absolute veto on any review in this case does not seem to be the current orientation of the Court, although it does not grant the Council a broad competence of judicial review.

The STF's adherence to the shared care of defenders of a restricted and limited power of non-application of laws that are unconstitutional by administrative bodies is also noted. The Court invariably has a concern to single out the situation of the $\mathrm{CNJ}$ in the context of the administrative bodies in general. Thus, coinciding with the argumentative alerts seen in the previous item, the precedents point out that the $\mathrm{CNJ}$ is substantially made up of renowned jurists of broad jurisdictional practice. What is captured in this step is the notion that this factor is important to admit the control of constitutionality (judicial review) by the body, since it reduces the risks of errors and reduces legal uncertainty.

Finally, STF case law highlights the fact that the concrete judicial review by the CNJ should be seen as truly exceptional. It is accepted this judicial review by CNJ if the Council is applying consolidated case law in the STF on the matter it is examining.

\footnotetext{
22 It is important to note that the decision of the STF, Pet 4656 / PB, Petição, Relatora: Mina. Cármen Lúcia, Julgamento: 19/12/2016, Voto do Min. Luiz Fux, Órgão Julgador: Tribunal Pleno, inaugurated a new vision of the powers of the $\mathrm{CNJ}$, combining the judicial control of constitutionality of administrative acts from article $37, \mathrm{CF} / 88$, which is provided in item II of $\S 4$ of article $103-\mathrm{B}, \mathrm{CF} / 88$, with the regulatory power attributed to the National Council of Justice. This regulatory power results from item I of $\S 4$ of art. 103-B, in which the Council has the duty to "ensure the autonomy of the Judiciary and compliance with the Statute of the Judiciary, and may issue regulatory acts, within the scope of its competence, or recommend meatsures". On the regulatory power of the CNJ, see PEDERSOLI, 2011.
} 


\section{REFERENCES}

BAHIA. Lei Estadual no. 13.555/2016. DOE de 30/04/2016. Disponível em: https://www.legisweb.com.br/legislacao/?id=319882. Acesso em: 29/07/2019.

BERCOVICI, Gilberto. Controle externo do judiciário e a soberania popular. In: TAVARES, André Ramos; LENZA, Pedro; ALARCÓN, Pietro de Jesús Lora. Reforma do judiciário: analisada e comentada. São Paulo: Método, 2005, p. 185-191.

CAVALCANTI, Alessandra Damian et al. Estudos do SINDIRECEITA, mimeo.

CANOTILHO, José Joaquim Gomes. Constitucionalismo e geologia da good governance. In: "Brancosos" e interconstitucionalidade: itinerários dos discursos sobre a historicidade constitucional. 2. ed. Coimbra: Almedina, 2008, p. 325334

CLÈVE, Clèmerson Merlin. Poder Judiciário: autonomia e justiça. In: CLÈVE, Clèmerson Merlin; BARROSO, Luís Roberto. Doutrinas essenciais de direito constitucional. V. 4, São Paulo: Editora RT, 2011, p. 659-675.

CNJ - Conselho Nacional de Justiça, Pedido de providências $\mathbf{N}^{\circ} 200910000001038$, Relator Conselheiro Jorge Antonio Maurique, Plenário, Julgamento em 28/04/2009.

Procedimento de controle administrativo 200910000018762, Relator: Antonio Umberto de Souza Júnior, Plenário, Julgamento em 09/06/2009.

Pedido de providências $n$ no. 0005230-38.2009.2.00.0000, Relator: José Adonis Callou de Araújo Sá, Julgamento: 01/06/2010.

Medida cautelar no procedimento de controle administrativo no 0006624-41.2013.2.00.0000, Relator Rubens Curado, Julgamento em 12/11/2013.

Procedimento de controle administrativo no. 000180993.2016.2.00.0000, Relator para o Acórdão Valdetário Andrade Monteiro, Julgado em $15 / 05 / 2018 a$.

Cármen Lúcia: "CNJ não declara inconstitucionalidade de norma nenhuma". 2018b. Disponível em: https://www.cni.jus.br/noticias/cnj/86222-carmenlucia-cnj-nao-declara-inconstitucionalidade-de-norma-nenhuma. Acesso em: 28/07/2019.

2019.

. Recomendação no. 38 da Corregedoria Nacional de Justiça de 2019.

COSTA, Pietro. Teoria e crítica do Estado de Direito. In: COSTA, Pietro; ZOLO, Danilo. O Estado de direito: história, teoria, crítica. Tradução de Carlo Alberto Dastoli. São 
Paulo: Martins Fontes, 2006, p. 95-198.

FEREJOHN, John. Judicializing politics, politicizing law. Law and contemporary problems. V. 65, n. 3, p. 41-69, 2002.

FIOROVANTI, Maurizio. Constitución. De la antigüedad a nuestros días. Tradução de Manuel Martínez Neira. Madrid: Trotta, 2001.

HÄBERLE, Peter. Hermenêutica constitucional: a sociedade aberta dos intérpretes da Constituição. Porto Alegre: Sergio Antonio Fabris Editor, 1997.

JONES, Brian Christopher. Constitutional paternalism: the rise and (problematic) use of constitutional guardian Rhetoric. New York University journal of international law \& politics, vol. 51, n. 3, p. 773-806, Spring 2019.

LAURENTIIS, Lucas Catib de. Entre lei e constituição: a administração pública e o controle de constitucionalidade no direito brasileiro. RDA - Revista de direito administrativo, Rio de Janeiro, v. 260, p. 132-166, maio/ago. 2012.

KELSEN, Hans. Quién debe ser el defensor de la Constitución? Tradução de Roberto J. Brie. Madrid: Tecnos, 1995.

MACEDO, José Arthur Castillo de. (Hiper)presidencialismo brasileiro: esse outro esquecido. In: CLĖVE, Clèmerson Merlin (Org.). Direito constitucional brasileiro. São Paulo: Revista dos Tribunais, 2014, v. 2, p. 496-518.

MATO GROSSO. Lei no. 8943 de 29 de Julho de 2008. DO de 29/07/2008.Disponível em: http://www.al.mt.gov.br/storage/webdisco/leis/lei-8943-2008.pdf. Acesso em: 22/07/2019.

MARRAFON, Marco Aurélio; ROBL FILHO, Ilton Norberto. A crise das fontes jurídicas enquanto crise do Estado Democrático de Direito. Revista eletrônica direito e política, Programa de Pós-Graduação Stricto Sensu em Ciência Jurídica da UNIVALI, Itajaí, v.9, n.3, p. 1441-1442, 3ำ quadrimestre de 2014.

MARRAFON, Marco Aurélio. O caráter complexo da decisão em matéria constitucional. Rio de Janeiro: Lúmen Juris, 2010.

MATOS, André Salgado de. A fiscalização administrativa da constitucionalidade. Coimbra, Almedina, 2004.

MENDES, Gilmar Ferreira. O Poder Executivo e o Poder Legislativo no controle de constitucionalidade. Revista de informação legislativa. Brasília, n. 134, p. 18-19, abr./jun. 1997. 
O'DONNELL, Guilhermo. Accountability Horizontal e novas poliarquias. Lua nova: revista de cultura e política, n. 44, São Paulo, p. 27-54, 1998.

PEDERSOLI, Christiane Vieira Soares. Conselho Nacional de Justiça: atribuição regulamentar no Brasil e no direito comparado. Belo Horizonte: Editora Fórum, 2011.

PGR, N. 59/2019 - AJA/SGJ/PGR, sistema único n. PGR-MANIFESTAÇÃO$44629 / 2019$.

ROBL FILHO, Ilton Norberto. Conselho nacional de justiça: Estado democrático de direito e accountability. São Paulo: Saraiva, 2012.

AREL FAAR, Ariquemes, RO, v. 5, n. 1, p. 40-67, jan. 2017.

ROBL FILHO, Ilton Norberto, SCHELEDER, Adriana Fasolo Pilati. Teoria da constituição, jurisdição constitucional e democracia: uma análise das camadas clássica (Schmitt) e pós-situação clássica (Loewenstein) no direito constitucional. In: ROBL FILHO, Ilton Norberto, SCHELEDER, Adriana Fasolo Pilati. Constitucionalismo e democracia. Itajaí: Univali, 2016, p. 9-41.

RUIZ, Gregorio. Federalismo judicial: el modelo americano. Madrid: Editorial Civitas, 1994.

SCHEDLER, Andreas. Conceptualizing accountability. In: DIAMOND, Larry; PLATTNER, Marc F.; SCHEDLER, Andreas (orgs). The self-restraining state: power and accountability in new democracies. Colorado: Lynne Rienner Publishers, 1999, p. 13-28.

STF, ADI 221/MC, Ação direta de inconstitucionalidade - medida cautelar, Relator: Min. Moreira Alves, Julgamento: 29/03/1990.

ADI 3367 / DF, Ação direta de inconstitucionalidade, Relator: Min. Cezar Peluso, Julgamento: 13/04/2005.

ADC $12 \mathrm{MC} / \mathrm{DF}$, Medida cautelar na ação declaratória de constitucionalidade, Relator: Min. Carlos Britto, Julgamento: 16/02/2006a.

MS 25888 MC, Mandado de segurança - medida cautelar, Relator: Min. Gilmar Mendes, Decisão de 22/03/2006, DJ 29/03/2006b.

. Questão de ordem em petição 3.674-3, Relator: Min. Sepúlveda Pertence, Plenário, Julgamento em 04/10/2006c.

ADI 3233 / PB, Ação direta de inconstitucionalidade, Relator: Min. Joaquim Barbosa, Julgamento: 10/05/2007, Órgão Julgador: Tribunal Pleno. 
. ADC 12 / DF, Ação declaratória de constitucionalidade, Relator: Min. Carlos Britto, Julgamento: 20/08/2008.

AC 2390 MC / PB, Medida cautelar em ação cautelar, Relatora: Mina. Cármen Lúcia, Julgamento: 07/08/2009.

MS 28141/MT, Mandado de Segurança, Relator: Min. Ricardo Lewandowski, Julgamento: 10/02/2011a, Órgão Julgador: Tribunal Pleno.

MS 29.118 AgR, Agravo regimental em mandado de segurança, Relator: Mina. Cármen Lúcia, Julgamento em 02/03/2011, Plenário, DJE de 14/04/2011b.

Ag. Reg. na AO no. 1.706/DF, Agravo regimental na ação originária, Relator: Min. Celso de Mello, Plenário, Julgamento em 18/12/2013.

Pet 4656 / PB, Petição, Relatora: Mina. Cármen Lúcia, Julgamento: 19/12/2016, Órgão Julgador: Tribunal Pleno.

MS 32582 MC-AgR, Agravo regimental na medida cautelar em mandado de segurança, Relator: Min. Celso de Mello, Julgamento: 15/06/2018.

MS 36549 MC, Medida cautelar em mandado de segurança, Relator: Min. Marco Aurélio, DJe 01/07/2019.

TOMIO, Fabrício Ricardo de Limas, ROBL FILHO, Ilton Norberto. Accountability e independência judiciais: uma análise da competência do conselho nacional de justiça (CNJ). Revista de sociologia e política, v. 21, № 45: 29-46, mar. 2013.

WEILER, J. H. H. The geology of international law - governance, democracy and legitimacy. Zeitschrift für ausländisches öffentliches recht und völkrecht. Heidelberg, p. 548-549, 2004. 